\title{
The Study of Microbiological Safety of Germinated Seeds of Broad Beans in the Process of their Production and Storage
}

\author{
Gurbanov NH*, Gurbanova RI, Gadimova NS, Akhundova NA, and Mageramova MH
}

Azerbaijan State University of Economics (UNEC), “Food products' technology” department, Baku, Azerbaijan

${ }^{*}$ Corresponding author: Gurbanov NH, Assistant Professor, Azerbaijan State University of Economics (UNEC), "Food products' technology" department, AZ-1134, Baku city, 4th district, Asim Maharramov street 68, apartment 86, Baku, Azerbaijan, Tel: +994 05033877 20, E-mail: nusratgurbanov@hotmail.com

Citation: Gurbanov NH, Gurbanova RI, Gadimova NS, Akhundova NA, Mageramova MH (2018) The Study of Microbiological Safety of Germinated Seeds of Broad Beans in the Process of their Production and Storage. J Adv Food Tech 1(1): 105. doi: 10.15744/2639-3328.1.105

Received Date: July 4, 2018 Accepted Date: August 17, 2018 Published Date: August 20, 2018

\begin{abstract}
Microbiological purity of the finished products based on bio-activated seed and grain requires special attention, as the level of moisture in bio-activated raw materials is $42-44 \%$, which is a pleasant environment for the development of microorganisms. Therefore, the search for effective ways to increase the microbiological safety of sprouted raw materials and finished products on their basis is always actual.

Based on conducted studies, it was found that, it is recommended to expose the dry seeds to short-term hydrothermal (moisturethermal) treatment, simultaneously removing the seed's shell in order to improve the microbiological purity of bio-activated faba bean seeds.

In the process of obtaining germinated products, both at the beginning of seed preparation and pre-soaking, it is possible to significantly reduce the microbiological contamination, due to the soft mode of preliminary short-term hydrothermal treatment which removes the most charged part of the beans, the seed's shell. Along with this, accelerates the process of preparation of the propagated samples, increasing their yield and improving the nutritional value of the final product.

Proceeding from the foregoing, the issues of the change in the microbiological contamination of germinating seeds of broad beans in the process of receiving and storing them in a plastic bag in the cold $\left(+6^{\circ} \mathrm{C}\right)$ were studied too.

It was found that in the samples of broad bean seeds, the decrease in the development of microflora in them occurs in several forms. Thus, preliminary short-term hydrothermal treatment of dry seeds in order to accelerate the process of bioactivation and scaling simultaneously reduces microbiological contamination. This is primarily achieved by the effect of high temperature effect on the seed coat, where the most undesirable microorganisms are collected.

It was revealed that natural seeds in the process of preparation for germination have two times more sowing than the seeds freed from bran covering by preliminary moisture-heat treatment. A similar picture is also observed in the ready-sprouted samples, i.e. seeds sprouted in kind have about two times more sowing than seeds sprouted in a rusty form.

In addition, studies have shown that storing sprouted seeds of faba beans in an insoluble form at a temperature of $+6^{\circ} \mathrm{C}$ in polyethylene bags up to four days ensures their safety.

Thus, the application of a directional regime for germination of broad bean seeds in an insoluble form makes it possible to obtain a seed mass (semi-finished product) from a less microbiological sowing which is stable for storage and use.
\end{abstract}

Keywords: Broad bean seeds; Germination in peeled form; Microbiological indicators

\section{Introduction}

Germinated cereal products, likewise natural, are being used in health-improving diets [1-3]. Research conducted last years in this direction for the inventions of the products of functional purpose have obtained huge scales [4-8].

Based on it, our research with broad bean seeds, which are called "pakhla" in the folklore like traditional protein-containing raw material, widely used in cooking, in order to get germinated composition and food products from it deserves attention [9-13]. 
It is well known, that wheat and other cereals are germinated with the temperature of $20-40{ }^{\circ} \mathrm{C}$ [14-16]. Herewith, active growth of foreign microflora was observed which degrades the safety of germinated raw material, as germinated grain contains in average $42-44 \%$ moisture, which is a favorable environment for development of microorganisms $[17,18]$.

Usually for decreasing the amount of pathogenic microorganisms in the process of germination, a number of ways is used - mixing in the water simultaneously soaking antimicrobial agents, processing raw material by them, or reduction of the germination time and other ways. In latter (reduction of the germination time), it is achieved at the expense of exercitation of enzyme preparations, destroying membranes of cereal, in which main ingredients are cellulose and some hard-hydrolysable polysaccharides (lignin, pentosane, pectin substances, protopectin and etc.).

In spite of a certain significance of indicated components of the membrane, they prevent acceleration of biochemical reactions, contain foreign microorganisms and decrease the nutrition value in the process of germination. Most of the bean seeds in the membrane contain contemporary anti-nutritional substances (oligosaccharides, antitrypsin and antipepsin enzymes and etc.), which further decrease food-producing values and physiological significance of the processed cereal.

In a word, despite of the popularity and high nutrition values, derived products in terms of germinated cereal and their germinates, primarily leguminosaes, possess major deficiencies - quick mold formation, propensity for medical problem with potato diseases and others. Especially this type of the product is most of the time primarily offered to the usage in raw form by way of additives for salads, porridges, soups, and others. With that, washing them before using does not entirely provide the level of their microbiological safety.

All this require academic specialists to develop safer and secure methods of derivation of germinated raw material and semifinished goods for nutrition ration.

Proposed modified method by us of having the germinated broad bean seeds, in our view, meets above indicated requirements and makes impossible the promotion of the level of microbial contamination of the germinated production. As in the process of germination of the latter both at the start of preparation of the seeds and their preliminary soaking, results in significant decrease of microbiological filth of the raw material, due to smooth regulation of the preliminary short hydrothermal treatment for removing the most infected details of the beans - seed's shell. With that, the process of preparations of the germinated samples, promotion of their appearance and improvement of nutritive value of the ready production increases.

This article indicates the results of the exploration of microbiological safety of the preliminary peeled and bio activated (germinated) broad bean seeds from the Windsor variety, growing in south regions of Azerbaijan Republic, whose germination was implemented by us with former suggested method [19]. Whereby, used raw materials in content of toxiferous elements (mg/kg), pesticides (mg/ $\mathrm{kg}$ ) and mycotoxins $(\mathrm{mg} / \mathrm{kg}$ ) were in line with demands of current standards, in other words were safe for germination.

Thus, in order to decrease the microbial contamination of germinated seeds of broad beans and the time of its germination, increase the activity of endoenzymes, increase the production of the germinates in a developed process, short-lived special wetheat treatment and removing bran covering, before soaking the raw material, was applied. After that the peeled seeds (seed lobe) were soaked in drinkable municipal water at the temperature of $20^{\circ} \pm 4^{\circ} \mathrm{C}$ (hydro modulus composed $1: 10$ ) during 21 hours, then were germinated during 72 hours. Every 12 hours the amount of the germinated seeds to their total number were written down (Figure 1).

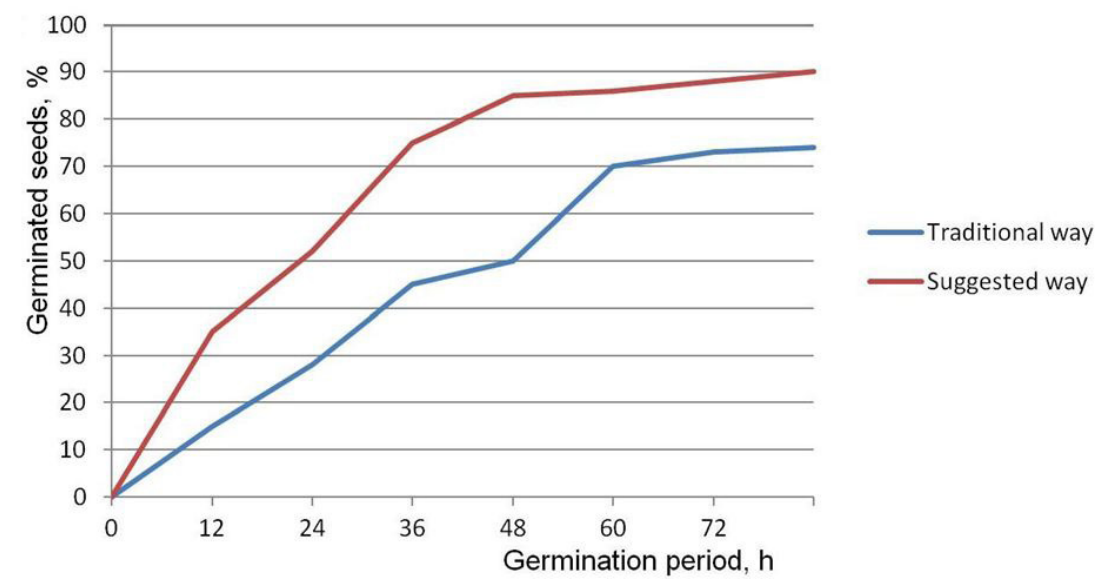

Figure 1: The dynamics of sprouting of the broad bean seeds depending on germination method 1.Traditional method (natural unpeeled seeds) 2.Suggested method (peeled seeds)

External appearance of the seeds of broad beans before and after germination, depending on method of preproduction of the raw material, is shown in Figure 2. 

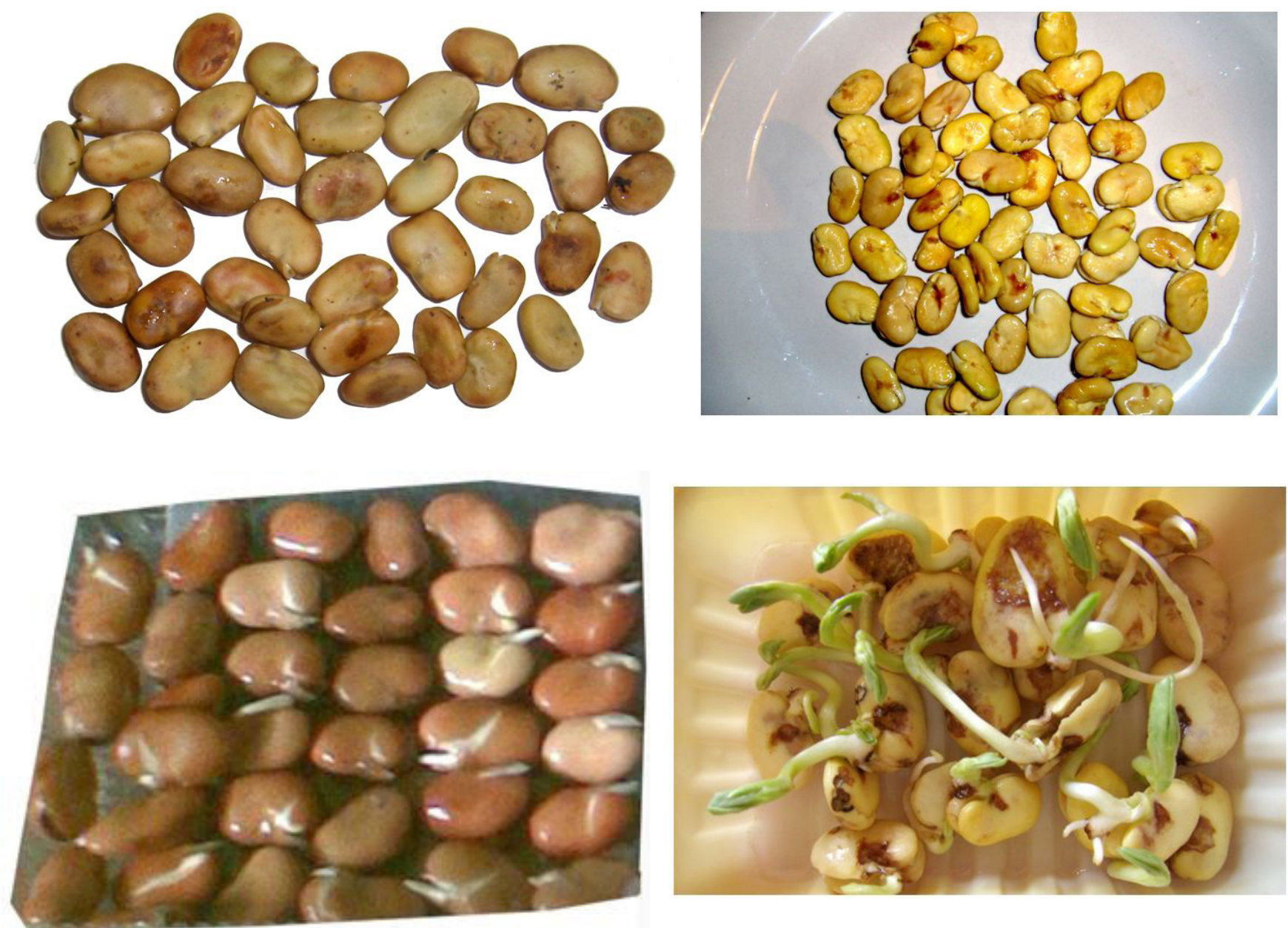

Figure 2: External appearance of the seeds of broad beans before and after germination depending on method of preproduction of the raw material (A) natural seeds; (B) Peeled seeds; (C) Germinated by traditional way

It should be noticed, that in the process of germination of peeled bean samples by suggested method, they produce double sprouts. However, at natural unpeeled samples it is hardly in evidence, in other words they possess single sprouts. Besides, the process of germination happens much more slowly in comparison to traditional way of germination.

\section{Results and Discussion}

The results of research on changes in morphological factors and appearance of the seeds in the process of germination are shown in the Table 1.

\begin{tabular}{|c|c|c|c|c|c|c|c|}
\hline \multirow{2}{*}{$\begin{array}{c}\text { Kind, used for } \\
\text { germination of seeds }\end{array}$} & \multicolumn{2}{|c|}{$\begin{array}{c}\text { Average dimensions } \\
\text { of dry bean seeds, sm }\end{array}$} & \multicolumn{2}{|c|}{$\begin{array}{c}\text { Middle dimensions of alone } \\
\text { and binominal sprouts after } \\
\text { germination, sm }\end{array}$} & $\begin{array}{c}\text { Middle mass of unpeeled } \\
\text { and peeled germinated seeds } \\
\text { with germinants (g) }\end{array}$ & $\begin{array}{c}\text { Alternation of mass } \\
\text { of the seeds after } \\
\text { germination, (\%) }\end{array}$ \\
\cline { 2 - 8 } & Length & Width & 1-st & 2-nd & $\begin{array}{c}\text { Before } \\
\text { germination }\end{array}$ & $\begin{array}{c}\text { After } \\
\text { germination }\end{array}$ & \\
\hline With a husk (unpeeled) & 3,0 & 2,0 & 1,9 & - & 2,7 & 7,3 & 267 \\
\hline Without a husk (peeled) & 2,8 & 1,8 & 2,5 & 1,6 & 3,0 & 11,5 & 380 \\
\hline
\end{tabular}

As seen from Table 1 and Figure 1, preproduction and removal of shell, simultaneously improving the arising sprouts, increase the dynamic of their germination. The microbiological contamination of broad bean seeds, germinated by traditional and suggested way, was determined by well-knowing methods [20-22].

The results on determination of changes in microbiological factors of broad bean seeds in the process of germination are shown in the Table 2. As seen in the Table 2, natural seeds in the process of preparation for germination possess twice as large contamination, than the seeds removed from shell by applying preliminary hydrothermal treatment. The same is observed in the finished germinated samples.

Taking into account the high quality and quantitative factors of germinated broad bean seeds by suggested technology and 
perspective of their usage for deriving functional nutritional products, it is considered to be desirable to further research the condition of microbial contamination of germinated samples in the process of storage, as this products have a short storage time in spite of popularity.

\begin{tabular}{|c|c|c|c|c|c|}
\hline No & The technology of germination & Microbiological attributes afloat seeds, CFU, g & & & \\
\hline & & $\begin{array}{l}\text { Mesophilic aerobic and facultative anaerobic } \\
\text { microorganisms }\end{array}$ & $\begin{array}{l}\mathrm{CB} \text { in } 0,1 \mathrm{~g} \\
\text { seeds }\end{array}$ & Yeast & Fungus \\
\hline \multirow[t]{3}{*}{ I } & Germination of natural unpeeled seeds: & & & & \\
\hline & -seeds after soaking & $6,0 \bullet 10^{5}$ & is absent & not detected & not detected \\
\hline & -seeds after germination & $1,6 \cdot 10^{12}$ & Elicited & $3,0 \cdot 10^{3}$ & 30 \\
\hline \multirow[t]{3}{*}{ II } & Germination of peeled seeds: & & & & \\
\hline & -seed lobes after soaking & $3,0 \cdot 10^{2}$ & is absent & not detected & not detected \\
\hline & -seed lobes after germination & $2,5 \cdot 10^{6}$ & is absent & $<15$ & $<15$ \\
\hline
\end{tabular}

Thus, developed method of broad bean seeds germination in a peeled form on suggested technology, provides their microbiological stability. We are in opinion that, it occurs due to positive effect of preliminary hydrothermal treatment and soaking of seeds without shell in microflora condition in the process of their germination.

For this reason, in order to increase the drawdown period of germinates (including seed lobe) made from broad bean seeds and for prevention of their recontamination with microorganisms, germinated samples were dried on the air, kept in polythene bag weighing of $100-150 \mathrm{~g}$ in the refrigerator at $+6{ }^{\circ} \mathrm{C}$ till 5 days after washing. Research have shown that, the safety preservation of germinated seeds in polythene bags is provided up to four days, as after five days the bacterial load growths above accepted level of safety [23].

The results are shown in the Table 3.

\begin{tabular}{|c|c|c|c|}
\hline \multirow{2}{*}{ Indices } & \multicolumn{3}{|c|}{ Existence of microorganisms upon storage } \\
\cline { 2 - 4 } & 2 days & 4 days & 6 days \\
\hline MAFAM, CFU/g & $3,0 \bullet 10^{5}$ & $4,5 \bullet 10^{5}$ & $5,0 \bullet 10^{8}$ \\
\hline Fungus, CFU/g & not observed & not observed & traces \\
\hline Yeast, CFU/g & not observed & not observed & traces \\
\hline colibacillus bacteria, in 0,1 g is not allowed & is lacking & is lacking & is lacking \\
\hline
\end{tabular}

Table 3: The alternation of microbiologic indices of germinated seeds upon storage in polythene bags in the freeze $\left(+6{ }^{\circ} \mathrm{C}\right)$

Hence, the conducted research allow to draw the conclusion that, the usage of directed regime of bean seeds germination in peeled form allows not only to speed up the time for germination, but also to derive seed mass with the least microbial contamination.

\section{Conclusions}

1. Short-term moisture-thermal processing of seeds of broad beans for peeling and anti-nutritional factors reducing purposes provides a simultaneous improvement in the yield of seeds and their microbiological parameters during germination.

2. Removal of the fruit shell of broad bean seeds by moisture-thermal processing two times reduces the microbiological seeding of the initial seeds.

3. The storage technique of sprouted seeds of broad beans obtained by the proposed method, in polyethylene packaging at a temperature of $+6^{\circ} \mathrm{C}$, ensures the preservation of their safety up to 4 days.

\section{References}

1. Ehrenbergerova J (2008) Different barley cultivars as a source of green mass for improving nutrient balance in human diet [Fortschritte in der Saatguttechnologie und -untersuchung- ertragsorientierte]. Züchtungsstrategien für neue Verwertungsmöglichkeiten: 91-4.

2. Poqojeva AV (2006) Estimation of utilization efficiency of bread, made from germinated cereal, in dietary therapy late adulthood with cardiovascular diseases. Probl Nutr Moscow 5: 45-8.

3. Sabelnikova EA, Parfenov AI, Krums LM, Belousova NL (2010) The problem of the organization of dietary nutrition for patients with gluten-sensitive celiac disease in Russia. Exp Clin Gastroenterol 3: 107-10.

4. Bogatiryeva TG, Labutina NV, Belyavskaya IG, Yudina TA (2016) The technology of rye-wheaten bread in terms of corn ferments. Cereal products, Moscow, 9: 49-51.

5. Veber AL, Kazidub NG, Leonova SA, Jiarno M (2017) The deriving of biologically active element from germinated bean by way of its future reference. Cereal products, Moscow 6: 35-9.

6. Vidal-Valverde C, Frias J, Sotomayor C, Diaz-Pollan C, Fernandez M, et al. (1998) Nutrients and antinutritional factors in faba beans as affected by processing. Z Lebensm Unters Forsch A 207: 140-5. 
7. Borisenko LA, Bratsikhin AA, Borisenko AA (2009) New types of cereal based meat semi-finished products. Food industry 10: 16-7.

8. Leonova SA, Nutredinova OF, Fazilov MZ (2015) Technology of obtaining a national cereal product from the germinated grain of oats with addition of apples. Breadproducts 9: 52-3.

9. Gurbanov NH, Isgenderova MM, Hasanova ZP (2013) Germinated broad bean seeds - semi-finished product for manufactureof the functional nutritional products. Methods and technology of food production, IX International Scientific and technical conference.

10. Gurbanov NH, Gurbanova RI, Maharramova MH, Isgenderova MM (2017) Combined proteic-vitaminic salad in terms of germinated broad bean seeds. Collection of news «National academy of sciences of Azerbaijan. Ganja department 4: 134-44.

11. Gurbanov NH, Gurbanova RI, Maharramova MH, Isgenderova MM (2017) Variance examination of general chemical and amino acid composition, ferments strength of peeled broad bean seeds in the process of germination. Proceedings of Azerbaijan Agrarian University, Ganja 3: 45-9.

12. Gurbanov NH, Omarova EM, Gurbanova RI, Yusifzade SN (2014) Grain milk from germinated broad bean seeds for production of combined fermented milk drinks of functional purpose. Conference for 13th Anniversary of the National Institute of Food Technology.

13. Gurbanov NH, Omraova EM, Gasanova ZP (2015) Quantitative study of amino acid composition of faba bean seeds before and after of bio activation. X International Scientific and technical conference.

14. Shaskolskaya ND (2011) The most healthy food - sprouts. Publishing house «Vedi»: 16.

15. Osadchenko IM, Gorlov IF, Mosolova NI (2016) High technology of seed germination like elements for food intention. Food Indus Moscow 2: 44-6.

16. Berejnaya OV, Dubchov GG, Voyno LI (2015) Wheat germs ingredient for foodstuff. Food Indus Moscow 5: 26-9.

17. Jarkova IM, Malyutina TN (2016) Biomedical requirements and sanitary quality norms of vegetable and food products. Voronej, "VQIUT": 223.

18. Alexina NN (2017) Investigation of the influence of the hop structure on microbiological indicators of the bread quality from bio activated wheat grain. Bread products 6: 60-1.

19. Gurbanov NH, Maharramova MH, Gurbanova RI (2014) Bioactivation of broad beans (Faba vulgaris Moench) for deriving food compositions purpose of use. Microbiology Institute Transactions of Azerbaijan National Academy of sciences, Baku, 1: 149-54.

20. Fish Alliance (2011) GOST 26669-85 Nutritive and flavor products. Preparations of samples for microbiology testing, Russia.

21. Fish Alliance (2011) GOST 10444.15-94 Nutritive products. Methods of quantity measurement of mesophilic, aerobic and facultative anaerobic microorganisms, Russia.

22. Fish Alliance (2011) GOST P 54005-2010 Nutritive products. Methods of detecting and quantity determination of bacterium's of the family Enterobacteriaceae, Russia.

23. Shilov GY (2012) Microbiologic rationing of new species of food-stuff. Food Industry, Moscow, 12: 26-9.

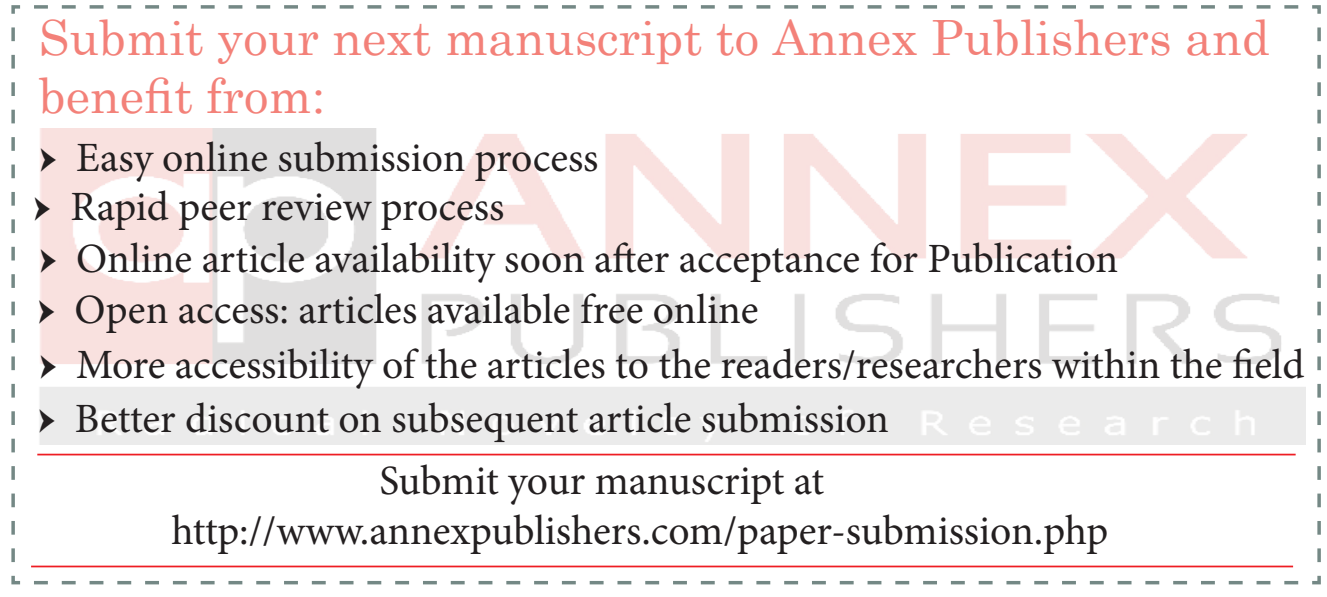

